\title{
EU Enlargement, Migration and the New Constitution
}

\author{
Hans-Werner Sinn*
}

\begin{abstract}
The paper deals with the effects of migration resulting from EU Eastern enlargement on the welfare states of Western Europe. Although migration is good in principle, as it yields gains from trade and specialization for all countries involved, it does so only if it meets with flexible labour markets and if it is not artificially induced by gifts of the welfare state. This is not the present state of affairs in Western Europe. In addition to measures that make labour markets more flexible, the introduction of delayed integration of working migrants and the home country principle for nonworking migrants is a rational reaction of the state. The proposed new EU constitution, which contains far-reaching rules for a European social union, should be amended accordingly. (JEL E2, F2, H0, J3, J6)
\end{abstract}

\section{Introduction}

1 May 2004 was the day on which the division of Europe into West and East was finally overcome. On this day, eight Eastern European countries joined the European Union, as well as Malta and Cyprus. Bulgaria and Romania are waiting in line, hoping to join in 2007 at the latest.

The Eastern European countries will enter into especially close economic relations with Western Europe and here especially with Germany and Austria. This will yield gains from trade and specialization for all and it will bring internal peace and general prosperity to Europe.

But there will also be problems because of the migration processes to be expected. Although migration is good in principle, this is only true if it meets with flexible labour markets and if it is not artificially induced by gifts of the welfare state. This is the topic of this contribution. It deals with the policies in the Western European countries and in the EU itself that must be pursued in order to let market forces unfold thereby providing Europe with a maximum of welfare and social security and maintain it in view of the expected migration. In this context, the new EU constitution, which contains far-reaching rules for a European social union, will be of central importance.

* University of Munich and Ifo Institute for Economic Research, Poschingerstraße 5, 81679 Munich, Germany.

This paper was prepared for the CESifo Economic Studies Conference on Migration and the Welfare State, Munich, 8 November 2003, organized by Gerhard Illing and Efraim Sadka. 


\section{Migration, wage differences and Eastern enlargement}

Eastern enlargement of the European Union will create substantial pressures for migration, as wage differences are still immense at present, as shown in Figure 1. In 2003, the average labour cost per hour in the accession countries was only 14 percent or one seventh of the west German labour cost per hour. Of course, due to the Balassa-Samuelson effect, the purchasing power parity differences are significantly smaller: the lower wages in the eastern European countries translate into lower prices for non-traded goods. However, even the differences in real wages are huge, in particular for migrant workers who save at least part of their earnings for future expenditure at home or who transfer the money to their families back home.

Figure 1

\section{Hourly labour costs $^{1)}$ in 2003}

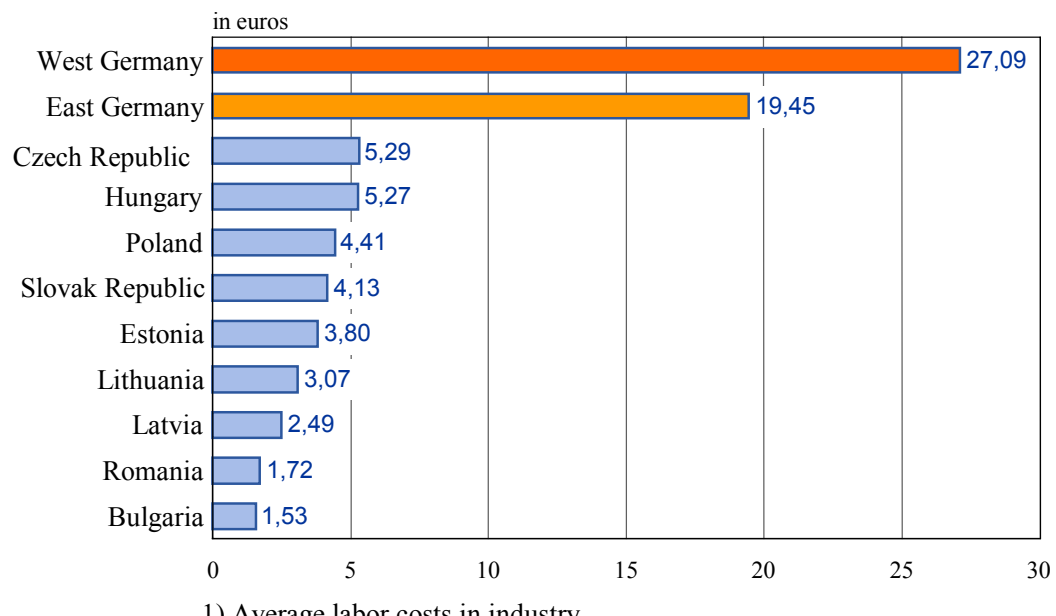

1) Average labor costs in industry.

Source: For the accession countries, the Eurostat figures for 2000 were extrapolated on the basis to the Eurostat press release no. 112 of September 15, 2004 or the ILO data base respectively. West Germany: Cologne Institute for Business Research; east Germany: Ifo Institute calculations. 
Bulgaria and Romania are not among the present accession countries, but the wage differences that exist vis-à-vis the other countries may also give rise to massive relocations of plants and migration pressures that will only be kept from exploding by administrative restrictions during the initial seven years. In 2010, when the transition period will have ended and free movement of labour will prevail, there will still be great wage differences despite a certain convergence. To date, the convergence has been 1.1 percent p. a. in Western Europe, and empirically the maximum for very rapid adjustment processes is considered to be 2 percent p. a., as a rule of thumb (see Sinn and Ochel 2003). At a maximum convergence rate of 2 percent p.a., wages of the accession countries will still amount to only 25 percent of west German wages in 2010 and 38 percent in 2020 .

In an econometric study commissioned by the German Ministry of Labour, the Ifo Institute projected that about 4 percent to 5 percent of the population of the countries joining the EU in 2004 will immigrate into the old EU countries within the next 15 years if immigration is not restricted. How large it will be with restrictions cannot be projected as the kind and the extent of the restrictions are not yet known. Lower figures are projected by Boeri and Brücker (2002) in a study commissioned by the EU, but this study inferred from the lack of reaction of migration to cyclical shocks that there will be little reaction to long-term wage differences, as criticised by Sinn and Werding (2001).

As proof of only little migration pressure, some have pointed to the immigration from Spain and Portugal, comparing Eastern EU enlargement to Southern EU enlargement. As migration to Germany was small at that time, a large movement of people from Eastern Europe is also not held to be likely.

The comparison is inappropriate, however. Firstly, income differences were much smaller in the Southern enlargement. At that time, the average wage income of Spaniards and Portuguese was close to 50 percent of west German wage income (see Sinn 2002, 107). This is quite different from the 15 percent of west German wages prevailing currently in the accession countries. Secondly, at that time, migration had already occurred before EU accession, whereas there has only been relatively little immigration from Eastern Europe to date, not accounting for the Eastern Europeans who, with nothing but a tourist visa, are working in the German underground economy. Those who have already emigrated, cannot emigrate once more after EU accession. This trivial fact should not be overlooked when searching for parallels (see Sinn et al. 2001).

In the period from 1960 to 1974-75, until the end of the Franco and Salazar dictatorships, there had already been mass emigration from Spain and Portugal. Although both countries had also been experiencing particularly high 
immigration from their former colonies at that time, net emigration of the Iberian population had already amounted to 5.5 percent p.a. during that period.

The possibility of emigration distinguished the dictatorships on the Iberian Peninsula from those in Eastern Europe. Whereas Franco and Salazar had allowed the free movement of people, the Soviet Union had closed off its territory with an Iron Curtain, which only very few surmounted at the risk of life and limb. When the Iron Curtain came down in 1989, many East Europeans did come West, and especially to Germany, but the West Europeans immediately replaced the Iron Curtain with a legal curtain by tightening their immigration and asylum laws. That is why the migration pressures from Eastern Europe continue unabatedly.

\section{Why migration is good in principle}

The West should not be afraid of migration, even if migration pressures are large. In principle, that is when labour markets are functioning and without distorting interventions of the state, it may be expected that the free movement of people is advantageous for Europe and all countries involved. This statement is true independently of whether the volume of migration is small or large. What immigrants can earn in Western Europe by far exceeds the loss of output at home caused by their emigration, and what they earn in the West is normally less than their output. Only the last immigrant receives a wage that equals his contribution to national output. Intramarginal immigrants receive less. Therefore both sides stand to gain. This is still true if the subjective and objective costs of migration are taken into account, because these costs are considered by the immigrant himself. If they exceeded the wage advantage there would be no migration.

Of course, wages will change as a result of migration. In the country of origin they will rise because labour is getting scarcer, and in Western Europe they will fall as the supply of labour increases. They must fall because otherwise the firms would not be interested in providing the additional jobs needed by the immigrants.

Because of the change in wages there will also be losers in the West as the result of Eastern enlargement of the EU. This concerns all those occupational groups that offer similar services on the labour market as the immigrants. In contrast, owners of capital and of real estate as well as skilled wage and salary earners who are not subject to the pressures of competition will belong to the winners, as demand rises for the factors of production they offer and they therefore benefit from higher prices and wages. In sum, the Western Europeans 
will gain from immigration, but only because the winners win more than the losers lose.

The reduction in wage differences between the country of origin and the country of destination is a necessary regulatory mechanism of the migration process, just as wages in general have a signalling and allocation function in a market economy. The shrinking wage differences will slow down the increase in the movement of people and will bring it to a halt at a point at which the wage difference is equal to the last immigrant's costs of migration. This immigrant is almost indifferent regarding his decision to migrate, and people with higher migration costs will prefer to stay at home. The equilibrating process will be supported by declining rents abroad and rising rents at home which both tend to reduce the gap in real wages.

At each point of time, the working population is optimally distributed between the countries involved. In Western Europe as well as in the country of origin, the firms will employ people until the last employee produces just as much value added as he costs. In each country real wages will therefore equal the real marginal value product of the workers, and the wage difference measures also the addition to total European output resulting from the migration of one additional worker. Since the real wage difference just equals the migration cost of the last migrant, the addition to total European GDP resulting from his migration is also just equal to these costs. The sum of the national products of both countries minus the migration costs of all those involved can no longer be changed by a bit more or less migration than the market would generate itself. This sum is maximized by the "invisible hand" of the market. Even a wise and all-knowing central planner, if such a person did exist, could not find an economically more efficient distribution of the working population between the two countries.

The distribution of the working population between West and East will not remain constant over time. Rather, because of the low wages in the countries of origin, there will be a continuous capital inflow into these countries that raises the productivity of labour there and induces the firms to demand more labour. Over the course of time this will result in further wage increases. Conversely, the capital outflow from Western Europe will result in wage reductions there, albeit perhaps only to reductions relative to the growth trend of wages. This will slow the flow of immigrants, and many of the foreigners who have come to Western Europe will decide to return to their home countries. Such a two-way migration flow has also been observed in past migration processes. Thus, most of the Italians who immigrated to Germany in the 1960s have meantime returned to Italy, and the Greeks, too, are gradually returning home. 
This favourable picture of the migration process is only true in principle, however, i.e. under the assumption of free markets and without any possibly distorting influences of the welfare state. In reality, the immigration to Western Europe during the past 30 years looked quite different, and that is the topic of the next two sections.

\section{Immigration into unemployment}

The major prerequisite for welfare raising effects of migration is wage flexibility. Only if wages decline of those occupational groups to which the immigration occurs, will employers be willing to create new jobs for the immigrating people. Only in that case will there be additional output in the country of immigration and only in that case will it be possible for this additional output to more than offset the reduction in output in the home country, including the costs of migration, making migration economically worthwhile.

Countries like Israel or the United States, whose labour markets have been able to absorb large numbers of immigrants, are characterized by such a flexibility of wages. In Israel, the unemployment rate even declined from 9.6 percent to 8.8 percent between 1990 and 2000, although the population grew by one quarter during this period. In the United States, population growth by immigration amounted to 19.3 percent or close to 40 million people from 1970 to 2000 . Yet the unemployment rate fell from 5.0 percent in 1970 to 4.0 percent in $2000 .{ }^{1}$ None of the two countries experienced any particular problems of integration due to immigration, and both succeeded in translating immigration into a growth surge. If the labour market is left alone, immigration is no problem but rather is of great advantage to the economy.

The countries of Western Europe, however, do not leave their labour markets alone. There is no wage flexibility of the American or Israeli type. The reason is the welfare state which offers attractive income opportunities for those who do not find a job by paying so-called replacement incomes like unemployment benefits, early retirement benefits and in particular social aid. The wage replacement benefits of the welfare state prevent domestic workers, who are facing competition from immigration, from being willing to accept lower wages.

1 US population: Economic Report of the President 2003, see http://w3.access.gpo.gov/eop/; US migration: US Bureau of the Census, Annual Geographical Mobility Rates by Type of Movement, 1947 - 2001, see http:/www.census.gov/; unemployment in Israel: Bank of Israel, Annual Report 1999, Statistical Appendix, see http://www.bankisrael.gov.il/; Israeli population: Central Bureau of Statistics Israel, Selected Data, Population, see http://www.cbs.gov.il/engindex.htm. 
Bounded from below by replacement incomes, West European wages of lowskilled workers follow a relatively rigid trend that obeys the wishes of the unions and the welfare politicians' ideas of equity instead of the dictates of the market. That is why the additional supply pressure of the immigrants does not lead to wage moderation. And because wages do not fall against the trend, no additional jobs are created. There is immigration into unemployment.

This is, by and large, the process that occurred in many West European countries, especially in Germany. It did not imply that all immigrants immediately and exclusively became unemployed themselves, i.e. that there was direct immigration into the arms of the welfare state. That would not have been possible for the sole reason that foreigners were not directly entitled to welfare benefits like unemployment assistance or social assistance, but only after having held a job. No, most immigrants took regular jobs, and nationals became unemployed instead. The revolving door of the labour market turns quickly. The immigrants succeeded in occupying many places in the revolving door that were then unavailable to the domestic workers.

A closer look at German conditions can illuminate the facts. From 1970, when for all practical purposes there still was no unemployment, until 2002, unemployment among the domestic population and the immigrants rose by 3.9 million people. During this period of time, net immigration amounted to 7.5 million people, including of course also non wage earners. Of these, about 3.1 million people work in the official labour market. This is roughly the increase in the number of domestic unemployed in the same period of time which was about 3.2 million. The additional unemployment among the domestic population during the past 30 years may essentially be explained by crowding out by immigrants.

Immigration into unemployment is entirely pointless from an economic point of view, because the immigrants are no longer available for production in their home country, and in the host country there is no additional output because jobs are only exchanged. The combined national product of the countries involved is smaller than it would have been and, in addition, there are still the costs of migration.

The developments in the German labour market are due to the logic of the wage replacement system and follow a very basic economic chain of effects. The wage replacement system of the welfare state itself is responsible for unemployment because it sets a minimum wage entitlement that a private employer has to meet in order for employment to pay for the worker. If this minimum wage entitlement exceeds the productivity of the jobs that would have to be created for full employment to exist, unemployment will result. If in this situation immigrants enter the labour market, who are willing to work at 
lower wages than the local wage earners because they are not or not fully eligible for wage replacement benefits until they will have worked long enough in Germany, then they will get the jobs and the nationals will be displaced to the extent that immigrants are available.

But there are no additional jobs because the immigrants will crowd only a fraction of the national labour force. The buffer for the decision whether to hire more or fewer people will only consist of the local unemployed who receive wage replacement benefits and therefore have high wage demands. This is not contradicted by the fact that over time the immigrants will also be eligible for wage replacement benefits, will also develop high wage demands and will themselves be pushed into unemployment.

One of the basic principles of the market economy is that the price and volume sold will only be determined by those suppliers in the market who have the highest costs and therefore demand the highest prices. If more low-cost suppliers enter the market, prices will decline and the quantity rise only if they have enough capacity to completely replace the high-cost suppliers. The same applies to the labour market. Those receiving wage replacement benefits from the welfare state are the high-cost suppliers in the sense that they stand to lose a lot by taking up a job and therefore have high wage demands. If lower-cost suppliers enter the labour market, this will also have no effect on the volume of employment or the general wage level, but will result in the replacement of the high-cost suppliers by the immigrants who will offer minimally lower wages or other small concessions in other areas of working conditions. Only after complete displacement would wages start declining and would it pay the firms to create additional jobs, but this case is not realistic for the labour market in view of the orders of magnitude involved. ${ }^{2}$

\section{The welfare state as an immigration magnet}

Even if measures were taken to make the labour market more flexible and to permit immigration into new jobs rather than into unemployment, a second problem would stand in the way of an optimal migration result. It derives from the redistribution activity of the welfare state. Since it is in the nature of the welfare state to take from the rich and give to the poor, immigration induced by wage differences is distorted. Skilled workers who would earn an aboveaverage labour income in Western Europe must pay something like an entrance fee, whereas less skilled workers who would earn a below-average income in

2 See Sinn (2004) for a formal treatment of this phenomenon in an explicit migration model with government set replacement incomes. 
the West receive a kind of migration premium that increases the incentive to immigrate beyond what can be explained by wage and productivity differences. For these reasons, the welfare state works like a two-pole magnet for the people who are willing to migrate. With one side it repels the rich net payers and with the other it pulls in the poor who rely on the state.

This redistribution occurs not only and not even essentially as a result of the instruments of social security, but primarily via regular budget items. The state levies taxes that rise in line with income, but it spends its funds more or less uniformly on everyone. Redistribution even occurs through the free availability of roads and bridges, of parks and public offices, of judges and policemen or of schools and universities. Everybody can avail himself of these services, but some pay more for them than others.

To date, the immigrants have been predominantly unskilled, or at least people who could only earn a below-average income in Germany. For one, this is in the nature of things as immigrants usually lack language skills. Then, too, it results from the forces of selection developed by the redistribution activities of the state. Because of their low income, the unskilled immigrants received, in addition to their value added, the redistribution gains of the state as a migration premium. Although they and their employers paid their taxes and social security contributions, they received more from the state than they had paid, and this effect was the stronger the lower the immigrants' skills and thus the lower their wages. The immigration magnet demonstrated its effects (see Borjas 1999).

Migration of these people would also have resulted in a welfare loss if there had never been the problem of immigration into unemployment. The very last immigrant, who is still coming but is almost indifferent, is a person whose migration causes a welfare loss equal to the redistribution gain. This person bears migration costs in excess of the increase in his wage and hence in his value added by being integrated into the more productive economy but equal to the redistribution gain. The funds this person receives do not raise his standard of living compared to having remained home, but the tax payers lose them entirely.

The question arises as to the actual size of the gifts presented by the state to the immigrants. In an extensive study based on the socio-economic panel, the Ifo Institute tried to estimate the flows of state benefits to the stock of immigrants in Germany in 1997. Account was taken of taxes, contributions, pensions, welfare benefits as well as all the indirect benefits from public goods. Public goods include, for example, roads, bridges, parks, environmental protection, the courts, the administration, the police, fire fighters and the like. The findings of the study are presented in Table 1 . 


\section{Table 1}

The fiscal externality of a migrant to Germany

\begin{tabular}{|l|rrr|}
\hline In euros & \multicolumn{3}{|c|}{ Length of stay (years) } \\
per immigrant und year & $0-10$ & $10-25$ & $25+$ \\
\hline Balance of state revenues / expenditures & & & \\
Health insurance & -590 & -43 & 49 \\
Pension insurance without child effect & 1.376 & 1.606 & 2.148 \\
Nursing insurance & 95 & 117 & 176 \\
Unemployment insurance & 127 & 217 & -519 \\
Taxes and tax-financed benefits & -3.375 & -3.227 & -1.001 \\
Total balance & -2.367 & -1.330 & $\mathbf{8 5 3}$ \\
Full child effect on pensions & 1.126 & 1.314 & 1.757 \\
Total balance with full child effect & -1.241 & -16 & 2.610 \\
\hline * Cash value of payments made and received excluding any child effects. \\
Legend: Using the socio-economic panel (6,810 surveyed households in Ger- \\
many) the stock of immigrants in west Germany was surveyed in 1997; it consists \\
of those persons of non-German citizenship who live in west Germany, natural- \\
ized persons and persons with mothers of non-Germany citizenship excluding \\
immigrants of German descent. \\
\hline
\end{tabular}

Source: Sinn et al. (2001); Sozioökonomisches Panel (SOEP).

Most public goods are impure public goods with congestion externalities. The utility of using roads, parks or the services of the police and the courts falls the more, the more users there are. Assuming that the jurisdictions providing the public goods operate at their optimal scale, it follows from the theorem of Mohring and Harwitz (1962) that the average cost of providing the public goods equals the marginal social congestion cost. Thus, the cost estimates given in the table can be interpreted as externalities the immigrants impose on the domestic population.

The table shows that immigrants paid less into health insurance than they received from the state, but made high net payments into the pension insurance system, because the discounted value of their payments exceeded the pension claims established. Unemployment insurance profited from those immigrants who had lived in Germany for less than 25 years and lost from those immigrants who had been in Germany longer than this. As the latter were not very numerous, unemployment insurance gained on balance. But the immigrants paid less in taxes than they received in the form of taxfinanced welfare benefits and public infrastructure services. In these areas the state experienced a big deficit. 
Immigrants who had been in Germany for less than ten years could realize, on balance, a net gain from redistribution of annually EUR 2,367 per head. This net gain can be interpreted as a migration premium.

The calculations are sensitive to the way the pension system is modelled. Following von Weizsäcker's and Thum's (2000) estimates for the German pension system, it was assumed that the implicit taxes immigrants to Germany pay are 55 percent of their gross contributions, i.e. that immigrants will receive pensions whose present value is 45 percent of what they contributed to the pension system (while Germans receive about 50 percent).

\section{The effect of immigrants' children}

Razin and Sadka (2004) correctly commented on an earlier draft of this paper that the fiscal balance could also take into account the implicit taxes paid by the children of immigrants. Indeed, as I argued and proved elsewhere (Sinn 1990; 1997), the net fiscal externality of permanent immigrants who bring a whole dynasty of descendants into the country, equals the present value of the gross contributions of the first generation to the pension system. The basic reason is that the immigrants' pension will be financed by the children of the immigrants themselves. Razin and Sadka (1999) independently also showed this in paper that was based on a 1998 IMF working paper.

The last two lines of the table capture this effect by assuming that all immigrants will leave their descendants in the pension system. In that case, there is an additional benefit to the pension system of EUR 1,126 per immigrant. This effect reduces the absolute value of the negative net fiscal externality, but does not change its sign for the group of immigrants who stay for less than ten years. The negative net fiscal externality in Germany is EUR 1,241 per person and year in this case.

If the immigrants stay longer, they will also succeed in integrating themselves better into working life. Occupational skills and language proficiency will improve, and wages will rise in line with productivity. At higher wages, they will have to pay higher taxes, and the redistribution gain of the state will become bigger. Migrants, who resided in Germany for less than 25 years but for more than ten years, received during that period of their stay, on balance, only EUR 1,331 per year from the state if their children re-migrated with them, and with a full child effect they received about as much as they and their descendants contributed: the net fiscal balance in this case was only - EUR 16 which is smaller than any reasonable error margin. On average, during the whole period of their stay, including the first ten years, even these migrants' fiscal externality was negative significantly negative despite a full child effect. 
Migrants, who had resided in Germany for more than 25 years, made net payments to the state of EUR 853 per year during that period of their stay without the child effect and EUR 2,610 with the full child effect.

Unfortunately, as a rule, the immigrants did not stay long enough in Germany to become net payers. European guest worker migration typically is a return migration, unlike the permanent immigration of dynasties into the United States or Israel. About 60 percent of the immigrants surveyed had returned home after ten years, and only about 15 percent of them participated in the official labour market. After 25 years more than 80 percent had either died or had returned to their home country. While no information on the destiny of the immigrants' children is available, it seems very plausible that the vast majority of immigrants who return home within a decade are not leaving their offspring in Germany.

Apart from that, the children of immigrants who stay in the country have a hard time reaching average incomes during their subsequent working years. Typically, the second generation of immigrants remain below-average wage earners and therefore also impose a burden on the redistributive state.

Overall, there can be little doubt that immigration involves quite substantial fiscal losses for the welfare state, notwithstanding the gains from trade effects immigration is bringing about. This is a fortiori true if account is taken of the fact that the cost of the unemployed, who were crowded out of their jobs by immigrants because the welfare state offers them attractive replacement incomes, has not been included in the above figures. If this cost had been added, the figures would be very much higher.

To date, the direct losses of the state due to the redistribution gains received by the immigrants have been bearable. However, at least in Germany the cost of unemployment has been enormous and has largely contributed to the country's financial difficulties and ensuing benefit cuts. This situation could be exacerbated by a rise in the number of immigrants after the doors are opened to east Europeans which will be the case from 2011 onwards, at the latest, when the transition period for labour market integration ends. Other countries could then face similar difficulties and be forced to cut their benefits.

\section{Welfare states' competition for deterrence}

A reduction of welfare benefits is to be expected for the particular reason that the West European countries will enter a form of competition for deterrence vis-à-vis the economic refugees from Eastern Europe and other parts of the world. People willing to emigrate from Eastern Europe will compare potential 
countries of destination and will focus on those with the best welfare systems. To be sure, the decision to emigrate is a serious personal decision with many non-economic elements, but the choice of where to go, once the decision to leave one's home country has been made, will depend in large measure on the economic conditions in the potential countries of destination.

In this situation, each potential country of destination is well advised to think about the welfare benefits it wants to offer. If it is too generous it will attract the "boarders" of the state and may have to expect substantial expenditures. Therefore each country may tend to try being stingier than its neighbours. If, however, all Western European countries try to be stingier than their neighbours, this competition for deterrence will lead to a gradual erosion of the welfare state. ${ }^{3}$

This must be expected especially if migration is strengthened by network effects, that is, if it must be assumed that the initial immigrants from a certain country will be followed by their compatriots. The fear of network effects forces the welfare states in particular measure to beware of giving gifts to the migrants. What starts out as little gifts that can be financed may become financial burdens later on that are no longer bearable without a large-scale cutback of general welfare benefits (see Thum 2000). To be sure, these are slow-moving processes. The states' reactions frequently take many years. But they are led by powerful forces that could, in the long term, significantly change the face of the welfare state of Western European character. Germany is presently thinking about reducing its excessive welfare expenditures. Other countries already did that in the past, and again others will follow. The competition for deterrence has already begun.

It is possible that in these respects Europe will also gradually move in the direction of the United States that has no welfare state. The reason is not that Americans do not want one, rather that it could not survive the mobility of the people. In 1968, under Mayor Lindsey, New York City had tried to introduce more generous welfare rules along the European pattern, in order to get the poor off the streets. As a consequence, the poor from all over the country soon came to New York City and drove it to near bankruptcy. At least, in 1975, the banks refused to extend additional credit to the City. This forced the politicians to retract and return to the harsh welfare rules that exist in the entire country to this day. Washington, D.C. had similar experiences when it had to cut back its initially generous welfare programmes because the costs caused by the inflow of poor people spiralled of control. The only way to introduce a welfare state in the United States would be via actions of the federal government, but for

3 See Sinn (2003), and the references mentioned there. 
such actions the necessary majority cannot be found. Individual states that want to introduce higher benefits cannot succeed if they act in a competitive fashion, without the co-ordination with others.

There are basically only three ways to prevent Europe from having to face similar developments.

1. The free movement of EU citizens is prohibited.

2. Immigrants are not or not immediately integrated into the welfare system of the country of destination.

3. The welfare systems are harmonized, preventing erosion by competition.

The first way would not be meaningful. It would not conform to the Treaty of Rome and would prevent the welfare gains of migration as described above. The second was proposed by the Scientific Advisory Council attached to the German Ministry of Finance. This is a point to be dealt with later. The last way seems to be the solution being approached by the new EU constitution, whose draft was recently presented by the EU Constitutional Convention. This topic is so important for the future of Europe that a closer look at the draft is worthwhile.

\section{The new EU constitution: Twenty Mezzogiorni in Europe}

The Constitutional Convention, chaired by Valéry Giscard d'Estaing, the former French President, presented its proposal for the new EU constitution in June 2003, and with small amendments it was accepted in June 2004 at the Intergovernmental Conference in Brussels. This proposal is to be presented to the parliaments of the EU countries for ratification. Some countries have announced that they will also hold a referendum.

The new EU constitution defines the basic rights of the citizens of the Union, the decision-making bodies, the division of responsibilities among the European Union and the individual countries and much more. Above all, it safeguards the economic and currency union among the Member States, as well as the right to private property and the right of free movement so essential for a market economy.

There is the problem, however, that the constitution is unambiguously directed at the goal of creating a European social union. The constitutional proposal considers a European social union in many articles that deal with social coherence, solidarity, the fight against poverty, and similar things. Of particular importance are the following statements: 


\section{Article I-4, Fundamental freedoms and non-discrimination}

(2) In the field of application of the Constitution, and without prejudice to any of its specific provisions, any discrimination on grounds of nationality shall be prohibited.

Article I-8, Citizenship of the Union:

(1) Every national of a Member State shall be a citizen of the Union. Citizenship of the Union shall be additional to a national citizenship; it shall not replace it

(2) Citizens of the Union shall enjoy the rights and be subject to the duties provided for in the Constitution. They shall have the right to move and reside freely within the territory of the Member States; ...

Article II-34, Social security and social assistance

(1) The Union recognizes and respects the entitlement to social security benefits and social services providing protection in cases such as maternity, illness, industrial accidents, dependency or old age, and in the case of loss of employment, in accordance with the rules laid down by Union law and national laws and practices.

(2) Everyone residing and moving legally within the European Union is entitled to social security benefits and social advantages in accordance with Union law and national laws and pratices.

(3) In order to combat social exclusion and poverty, the Union recognises and respects the right to social and housing assistance so as to ensure a decent existence for all those who lack sufficient resources, in accordance with the rules laid down by Union law and national laws and practices.

These articles do not sound implausible at first reading. Union citizenship and free choice of residency are essential steps for a united Europe, and who would want to discriminate against citizens of other EU countries? The connection between the prohibition of discrimination and Article II-34 may have dire consequences, however. The constitution seems to say that a citizen of the Union may reside where he wants and that he is then entitled to the host country's full social security benefits and social advantages. And he must not be treated any differently from the nationals. The right to inclusion in the welfare state applies; so, in any case, says the legal jargon.

Although the above mentioned rights have already been granted before in Europe, by raising them to the level of constitutional rights they strengthen the idea of social inclusion. Unfortunately, they also strengthen the forces of erosion via a competition for deterrence à la United States, as described in the 
previous section. They truly create the ideal conditions for a full unfolding of this competition. The rules that are to strengthen the welfare state really weaken it because they provoke economic reactions of the advantaged citizens and the burdened states.

Presumably, the rights of inclusion of EU citizens will be further expanded by the new constitution compared to today's laws. To date, these rights have essentially applied to employed people. Those who change the country for reasons other than to take up work elsewhere, for example as tourists, as pensioners or as students, are given the cold shoulder by the host country's welfare state. They are not entitled to pensions, unemployment compensation or social assistance. A rather stringent principle of exclusion applies.

Limiting inclusion to employed people is no longer part of the new constitution, at least not explicitly. According to Article II-34, each EU citizen who resides legally in a country, and not only economically active people, is entitled to social security and social advantages like those granted to nationals.

It is true that the inclusion of non-employed persons remains limited despite the new constitution because its general provisions are being restricted by various EU Directives. The new Directive on Free Migration of May 2004, which will have to be implemented into national laws by June 2006, gives nonemployed the right to migrate wherever they want but requires that they have health insurance coverage and sufficient resources so as not to need welfare benefits in the host country. However, these requirements are limited to a period of five years. Thereafter, the migrants have the permanent right of residence even if they have no insurance coverage and do not command enough resources to live on. The full protection of the welfare state is then available. In this sense, there is now also the right of direct immigration of non-employed people into the welfare state, following the spirit of the new constitution. Interestingly enough, this right is not subject to the constraints on labour migration from Eastern Europe imposed during the transition period that lasts until 2010.

There will be an incentive for East European migrants to exchange their jobs back home for social assistance for themselves and their families after having lived in a western European EU country for five years. German social assistance, for example, is two to four times the Polish net wage depending on family status. Even if the gain comes only after five years of residence, it will be enough to enable the migrant to build a solid house back home, especially if he can use his time for a lucrative job in the underground economy of the host country. Black market work, too, will again earn him three to four times the wage at home. 
There is still some ambiguity as to the how the national governments will implement the new EU directive in detail. However, there can be little doubt that the migration decisions of job seekers will be distorted and that growing burdens on Europe's welfare states will result. Eastern enlargement has increased a problem from which the West European welfare states have suffered for at least two decades. It is therefore more than likely that over the course of the next few decades the competition for deterrence will intensify and the benefits of the welfare states will continue to be reduced.

Under these conditions it is foreseeable that voices for a harmonization of the welfare rules in Europe will become louder, voices that are already to be heard from the social policy makers in all countries, who demand a social union for Europe in addition to economic and currency union. Such a harmonization would be in agreement with Article I-14 (4) of the constitutional draft that explicitly provides for initiatives of the EU to coordinate the social policies of the member states.

Germany has already experienced the meaning of a social union with an extremely poor country, and the Italians, too, have experienced some of this. A social union implies uniform wage replacement incomes and thus uniform minimum wage demands in all parts of the European economy. In the economically weaker areas these minimum wage demands push the actual wages above the level that is compatible with full employment. Unemployment is the consequence. Unemployment compensation must then be paid by the richer regions via corresponding transfers. Germany's experiences with eastern Germany, and Italy's experiences with the Mezzogiorno, its southern regions, speak volumes. Neither country has so far found a solution to the permanent stagnation in their poor regions created by the social union.

The substantial problems already experienced by Germany and Italy could become a chronic disease of Europe as a whole. The reason may be easily recognized in Figure 2 that compares net wages of various countries and regions with the west German level of social assistance. Harmonization of social assistance at a level that Germany still considers appropriate would be the economic death knell of entire regions and countries in Europe. This would not only affect Eastern Europe. Many regions in the old EU would also be unable to pay the wages that would keep step with a harmonized social standard at the German level. There would not be two but twenty Mezzogiorni in Europe. Like the two existing ones, these twenty Mezzogiorni would have to be kept afloat by the funds of the still functioning regions. The current EU budget would multiply, and the EU would begin to become a serious financial problem for the Member States. 
Figure 2

Net wage income in Europe compared to West German

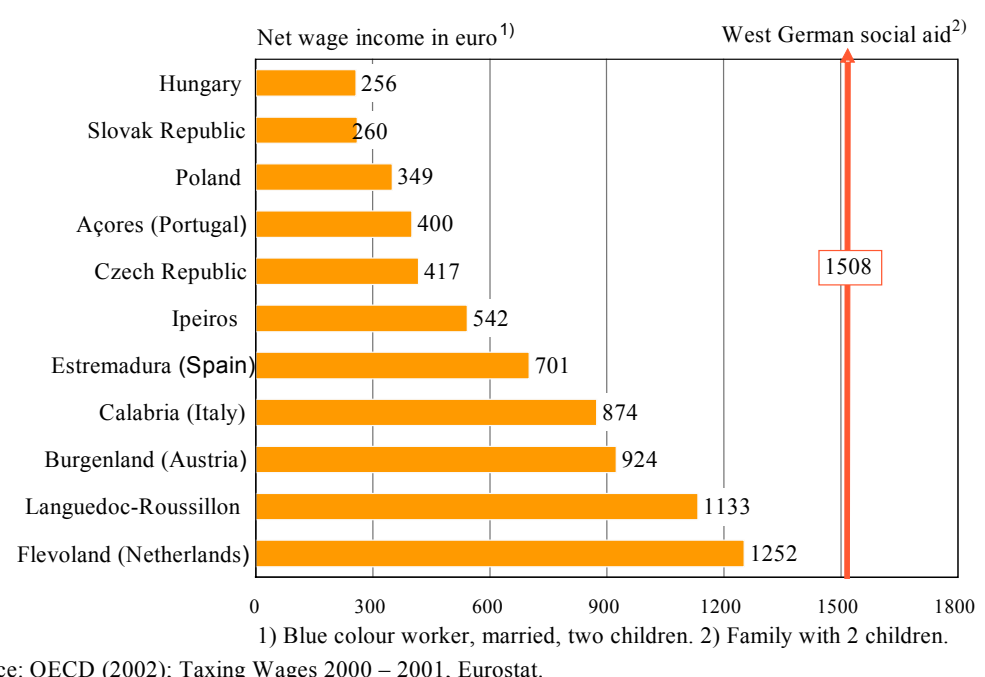

Source: OECD (2002); Taxing Wages 2000 - 2001, Eurostat.

\section{The solution: Delayed integration into the welfare system and home country principle}

In order to prevent the described risks two measures are conceivable. First, the system of wage replacement incomes could largely be abolished, and a system of wage supplements or wage subsidies along the lines of the American "earned income tax credit" could be introduced instead. Wage subsidies are no lower bounds on wages, but nevertheless help to maintain the incomes of the poor. They make wages flexible and prevent immigration into unemployment. Explicit proposals for Germany along these lines have been developed by the Ifo Institute, for example (see Sinn, Holzner, Meister, Ochel and Werding 2003).

Second, the inclusion of immigrants in the welfare state could be limited. The Scientific Advisory Council attached to the German Finance Ministry and similarly the Ifo Institute have recommended to place immigrant workers under the full protection of the social system only after some delay. During the period of delay, some tax financed social benefits should be curtailed so as to 
completely balance the fiscal current account. ${ }^{4}$ The motto would be that each EU citizen who wants to come is welcome, but does not receive any gifts.

The foreign worker is fully liable to taxes and contributions and he receives all entitlements to contribution-financed benefits as he does today, but taxfinanced benefits are initially not granted to the full extent. Most state services like free access to the public infrastructure and legal protection by the police and the courts would be available in full. But some benefits would be limited, like housing allowances, social assistance, child allowances for children remaining abroad or the availability of social housing. The limitations should be tailored in such a way that the fiscal account of the state is balanced. In the table above, there should thus no longer be a deficit of close to EUR 2,400 for the annual net cost of the state during the initial ten years, but a zero balance.

In addition, non-employed people should not be included in the social system of the host country but continue to demand support from their home countries. They could migrate wherever they want within the EU, but once they become needy without having worked there, they should be supported by their countries of origin.

Delayed integration of employed migrants combined with a home country principle for non-employed migrants would reduce the expected excess of migration to the economically efficient extent because migration premia would no longer be paid. Beyond that, it would take the pressure off the welfare states to meet the fiscal implications of migration with a general and undifferentiated reduction of redistributive payments. It would prevent the erosion of the welfare states caught in a competition for deterrence, and it would therefore also prevent the harmonization of social systems. Europe would not develop twenty Mezzogiorni, but would prosper in the economic differentiation that exists and, driven by the economic processes described above, would gradually converge, driven by the economic forces of factor price equalization.

In order for this development to happen, Article II-34 (2) of the draft for the EU Constitution could read:

Every person migrating legally from one EU country to another for the purpose of working there is, in principle, entitled to social security benefits and social advantages of the host country. However, during an initial waiting period the host country may limit tax-financed benefits. Non-employed persons must direct claims for social assistance at their home countries, regardless of the their country of residence.

4 See Scientific Advisory Council attached to the Ministry of Finance (2001), and Sinn et al. (2001). 
This would be sufficient, at least at the constitutional level, to establish the home country principle and the principle of delayed integration.

Of course, the political chances for such a modification of the constitution are slim. However, European parliaments should know what they vote for if they ratify the constitution in its present form. Should there be opposition to the constitution by one country there would be a chance to reconsider the case and modify the constitution before a second ratification round is begun.

The EU firmly holds on to a confirmation of the social inclusion rules that characterize the current legal status of the EU. However, it itself does not seem to feel overly comfortable with the idea of free migration into the Western European welfare states after Eastern enlargement. That is why it came up with the solution to give countries the right to suspend the free movement of accession country workers during a transition period of up to seven years after Eastern enlargement and to permit national restrictions for this period of time (see Husemann 2002). This is similar to the procedure during Southern enlargement, where the restrictions were removed early on, however, because the migration pressure was much less than expected. As was explained above, the pressure there had already been reduced before EU accession by the mass emigration during the time of dictatorship. In the case of Eastern Europe the situation is quite different because there was an Iron Curtain and because wages relative to those in the old EU countries are only a third of what they were in Spain and Portugal at the time of accession.

The EU Commission's proposal is not convincing for two reasons. Firstly, it only offers a temporary chance to influence the migration flows. The transition period after EU accession of the East European countries will pass quickly, and even thereafter the West European welfare state will maintain its function of immigration magnet for unskilled Eastern Europeans. ${ }^{5}$ Delayed integration and home country principle, in contrast, offer a permanent solution against welfare migration, because each immigrating individual is assigned an integration period during which he is only partially integrated. It works like a permanent brake on an excessive effect of the welfare state as immigration magnet and thus as a measure to protect this welfare state.

Secondly, from an economic point of view, quantitative restrictions are an inexact means to optimize the migration process. The people to be permitted to come are determined according to some rigid rules. Someone must stand at the gate and make a selection. It is doubtful whether, after such a selection, it is

5 Furthermore, as previously described, the Hungarian and Polish wages will only amount to one third of west German wages and less than half of east German wages, even at a maximum convergence speed of 2 percent per annum. This, too, will keep up the migration pressure. 
really those with the lowest subjective and objective migration costs who will come and who may be expected to achieve the highest productivity gain by changing their country of residency. Even the best bureaucrat cannot hope to match the market's selection ability. If he could, the planned economy would be as good as the market economy. The selection of productive activities from the large quantity of possible activities is the most important reason for the superiority of the market economy over the planned economy. To deny the market regarding such an important issue as the international migration of labour would really be a bad decision. Instead of distributing gifts to those selected by the state, it is much better, from an economic point of view, not to distribute any gifts for which the state has no money anyway, and to let EU citizens decide for themselves whether to migrate or not. Such a liberal solution would also agree much more with the spirit of the Treaty of Rome, which demands, among other things, the entirely free movement of all EU citizens.

\section{References}

Boeri, T. and H. Brücker (2002), The Impact of Eastern Enlargement on Employment and Labour Markets in the EU Member States, Final Report, European Integration Consortium, Berlin.

Borjas, G.J. (1999), "Immigration and welfare magnets", Journal of Labor Economics 17, 607-637.

Federal Statistics Office (2002), Statistical Yearbook 2003 for Foreign Countries, Table 13.4 "Average gross monthly earnings of industry and service workers in 2000", Wiesbaden.

Husemann, W. (2002), “Europa im Wandel - Zehn Fragen”, Bundesarbeitsblatt 3, 10-13.

Mohring, H. and M. Harwitz (1962), Highway Benefits. An Analytical Framework, Northwestern University Press, Chicago.

Razin, A. and E. Sadka (1999), "Migration and Pension with International Capital Mobility", Journal of Public Economics 74, 141-150.

Razin, A. and E. Sadka (2004), "Welfare Migration: Is the net Fiscal Burden a Good Measure of its Economic Impact on the Welfare of the Native-Born Population?", CESifo Economic Studies 50, 709-716. 
Scientific Advisory Council attached to the Ministry of Finance (2001), Report on "Freizügigkeit und soziale Sicherheit in Europa", Bundesministerium der Finanzen, Berlin.

Sinn, H.-W. (1990), "Allokations- und Distributionseffekte schrumpfender Bevölkerungen bei alternativen Alterssicherungssystemen in Modellen überlappender Generationen, comment on K. Jäger", in B. Gahlen, H. Hesse, H. J. Ramser and G. Bombach (eds.), Theorie und Politik der Sozialversicherung, Wirtschaftswissenschaftliches Seminar Ottobeuren Vol. 19, J. C. B. Mohr (Paul Siebeck), Tübingen, 99-101.

Sinn, H.-W. (1997), "The Value of Children and Immigrants in a Pay-as-yougo Pension System: A Proposal for a Transition to a Funded System", NBER Working Paper 6229, also: ifo Studien 47, 2001, 77-94.

Sinn, H.-W. (2002), "EU enlargement and the future of the welfare state", Scottish Journal of Political Economy 49, 104-115.

Sinn, H.-W. (2003), The New Systems Competition. Yrjö Jahnsson Lectures, Helsinki 1999, Basil Blackwell, Oxford.

Sinn, H.-W. (2004):,"Migration, Social Standards and Replacement Incomes. How to protect low-income workers in the industrialized countries against the forces of globalization and market integration", plenary lecture, International Institute of Public Finance, 60th annual meeting, Milano, August 2004, CESifo Working Paper 1265.

Sinn, H.-W., G. Flaig, M. Werding, S. Munz, N. Düll and H. Hofmann (2003), "EU Enlargement and Labour Mobility. Consequences for Labour Markets and Redistribution by the State in Germany", CESifo Research Reports, No.2, Ifo Institute for Economic Research, Munich.

Sinn, H.-W., Ch. Holzner, W. Meister, W. Ochel and M. Werding (2003), "Welfare to Work in Germany. A Proposal on How to Promote Employment", CESifo Research Reports, No. 1, Ifo Institute for Economic Research, Munich.

Sinn, H.-W. and W. Ochel (2003), "Social Union, Convergence and Migration", Journal of Common Market Studies 41, 869-896.

Sinn, H.-W. and M. Werding (2001), "Immigration Following EU Eastern Enlargement", CESifo Forum 2(2),40-47.

Thum, M. (2000), "EU Enlargement, Fiscal Competition and Network Migration", unpublished working paper, see author's website at http://www.tudresden.de/wwvwlfw/. 
Thum, M. und J. von Weizsäcker (2000), "Implizite Einkommensteuer als Meßlatte für die aktuellen Rentenreformvorschläge", Perspektiven der Wirtschaftspolitik 1, 453-468. 